\title{
WHO THREATENS JOURNALISTS IN PAKISTAN AND WHY? : AN ANALYSIS OF CONFESSIONS AND PERCEPTIONS OF WORKING JOURNALISTS
}

Received: 23-Oct-2020 | Accepted: 05-Jan-2021

Dr. Fazli Hussain ${ }^{1}$

\begin{abstract}
Free press works as watchdog to guard the freedom of expression but legal and societal protection and respect is predestined to sustain. In democratic societies, societal pressures, economical persuasions, political and ideological dilemmas and the parasitism of national interests while the ruler's ego, ruling interests and challenges of authorities in dictatorial regimes, are the areas bring to bear threats for journalists. A number of national and international studies proclaim press in Pakistan as not or partial free but don't estimate the agents and their surreptitious ends which this study is aimed to dig out and locate using base line survey in consultation with working journalists all around the country, providing equal opportunity to respond the close ended questionnaire constructed under Likert's Scale and Guttmann Scale on applicability's priorities. The study also investigates senior journalists to explore the criterion more in depth. The results lead to generalize the conclusion and provide with significant roadmap of policy making and evoke further research in the relevant areas.
\end{abstract}

Keyword: Threats, Journalist, Media, Professionalism, Pakistan

\author{
Author's Affiliation: \\ Institution: ILMA University ${ }^{1}$ \\ Country: Pakistan ${ }^{1}$ \\ Corrsponding Author's Email: *fazalhussainsheikh@yahoo.com
}

The material presented by the author(s) does not necessarily portray the view point of the editors and the management of the ILMA University, Pakistan.

2709-2232 (Online) (C2021, published by the ILMA University, Pakistan.

This is open access article under the license. https://creativecommons.org/licenses/by/4.0/ 


\section{INTRODUCTION}

Freedom of expression and freedom of press has always remained under threats and pressure on the line of its functioning as a watchdog, aggravating the opposition of wrongdoers. But after the world has entered in its post-modern age, challenges to the freedom of press have become vaguely complicated in their nature and exposures. In an interview with this author, BBC's correspondent Wasatullah Khan (2018) denoted that press and journalists survive under constant pressure and threats but with the passage of time a change has been witnessed in the media landscape of Pakistan and probably in the world. The change is that in past, challenges were open and the agents of threats were known but today challenges are blind and the actors are behind the curtain.

It is important to note that, the misuse of press in World War II instigated article 19 in the frame of Universal Declaration of Human Rights (1948) which proclaims freedom of expression and freedom of press against border restrictions and personal ambitions following by similar legislations in most of the signatory states but still the press is in chains and journalists are under threats around the globe.

In spite of constitutional guarantees and assurance in local and international instruments, Committee to Protect Journalists (CPJ), Freedom House (FH), Reporters without Border (RSF), Pakistan Press Foundation (PPF) and many other organizations persistently in their research claim that journalists are dwelling in state of fear, somewhere in declared and somewhere in hidden form, across the world including Pakistan.

This prevailed deteriorated situation with press and journalists, urges to locate threats, unveil threatening agents and to nominate reasons behind. The empirical study exploring the media environment in consultation with working journalists gauging their confessions and perceptions is the only way to set frame of regulations and ethics for inculcating media standards and for nourishing a pure media friendly and safe environment for journalists to work in.

So that this study attempts to investigate threats, to find out agents behind threats and to estimate reasons of threats that who threat journalists in Pakistan and why?, consulting working journalists across the country.

\section{LITERATURE REVIEW}

Press in contemporary democratic and dictatorial states of the world suffers from restrictions of divergent forms and from multiple directions in the name of national, regional interests or vested interests which not only divert the professional traits but also threaten press and journalists for journalistic activities. As the world entered in a formation of global village due to revolution in information technologies, led to amalgamation of economies, cultures and that gave birth to a number of complexes including the arena of journalism.

A report of International Press Freedom Mission to the United States proclaims in its executive summary that journalists in USA are facing with challenges like 
prosecutions, restriction on public information, national security, stigmatization by political leaders, physical attacks and arrests (IPFM, 2018). The report locates security risks and its dimensions in the United State of America explicitly.

In Pakistan's contexture, Sadia Jamil (2018) concludes that journalists in the country are at stake in the area of physical, economical, emotional and psychological stress, pressure and threats. She finds that due to security dilemmas prevailing in the state, journalists exercise self-censorship to shield themselves from the diverged reactions in the line of their duties.

Similarly, Furquan Ameen Siddiqui (2017) illustrates the threat's quandary in the media landscape of India, concluding that journalists are confronting with adverse circumstances of security risks and claim that demands from different parts of the country are made from time to time to frame effective law for the protection of journalists.

More in this regard, Sara Cook (2013) in her research work proves that in China, media is compelled to follow the government's lines, although the constitution guarantees freedom to it. She affirms that the press can never touch the sensitive areas regarding state's policies.

Antonis Skamnakis (2006) strengthening perceptions about global atrocities against the press, finds that in Greece, media-government relations stand on subsidy which is curtailing the freedom of expression and press. Péter Bajomi-Lázár (2003) also affirms that subsidiary to press is the curtailing agent for the press in Hungry. Herlambang Perdana Wiratraman (2014) in his research affirms that press freedom in Indonesia is under threats, although democracy is flourishing and that is due to socio-economic interests of stake-holders.

Concluding the scenario, threats to journalists were located by a working paper by Sarah Elliott, Mona Elibahtimy, Sharath Srinivasan (2012). Genera review of the paper demonstrates that journalists around the world are the targets of state and non-state agents and the rising trend of murders and injuring is alarming. The study finds that negative approaches of governments, lack of adequate laws and vested interests of stakeholders are endangering the profession of journalists.

All the aspects, diversities, impacts and effects are reflected by scholarly articles and researches on international stage but in Pakistan's perspective still quality and empirical study is needed to properly explore and locate the effects, implications and others areas of journalism in the state. This research will prove to be a precious addition in the realm of knowledge in this regard.

\section{METHODOLOGY}

This study employs quantitative method to locate the threats, sources of threats to journalists and their causes. A base-line survey with a close ended questionnaire generating confessions was distributed among 550 working journalists. The country's geographical region was divided into five clusters and equal number 
of questionnaires were distributed but 320 filled and complete from all angles of scientific research were recollected that denote $1.6 \%$ of the universe of the study which is 20000 that makes the sample able to be generalized.

More in this area, questionnaire was constructed under Guttmann Scale where "Yes" and "No" was the only choice for response and Likert's Scale was engineered where more dimensions were to be responded for scientific analysis like more, normal, less or no idea.

For further authenticated results and clarification of responses, thirty, six in each cluster, face-to-face interviews with senior journalists were also conducted across the country following Snowball method which is convenient in an environment of fear and distrust.

\section{FINDINGS AND DISCUSSION}

Face-to-face interviews resulted in affirmation of threats and in location of state and non-state agents including governing and opposition political parties, militants, traffickers, landlords and others as sources of threats. Causes of threats were also nominated as low level of rule of law, lack of dialogue mechanism among stake holders injunction with journalists, media owners, political and ideological factors, social activists and state institutions, deficiency of training and professional qualification of journalists, low salary or no salary packages of journalists and bribing culture in form of advertisements, gift and lucrative offers.

Interestingly, new dimensions were located by interviewees and were reinforced by most of them like geological division of threats and sources, beat based threats and the actors behind them, media persons' involvements in threat's creations, political affiliations and ideological affiliations, social diversity in the region, international relations and conflict's implications.

Interviews with senior journalists revealed that threats in investigative beats are more than normal beats. Similarly journalists are facing with lesser threats in political dimension than in religious or institutional part. In the same yardstick, consensus was found on the implications of national conflicts like Baloch separatists and Taliban factors and international squabbles like 9/11, Afghan unrests, Indian activities in Kashmir and on the line of control on the level of threats.

It was also reflected that in rural areas of the country, feudal lords, clergy and influential tribal lords put pressure on journalists and infiltrate in media content which ingenerate threats but in big cities, threats come from economical interest groups, land-grabbers, political and ideological groups and from state institutions. The empirical analysis of working journalists' perceptions and confessions is presented and are discussed as below to consolidate results.

\section{DEMOGRAPHICS}

Respondents of the survey are spread over the whole of the country. Five hundred 
and fifty questionnaires were distributed among working journalists, employing the Snowball technique but 320 were returned completed from all aspects which were processed statistically for understandable presentation and summarized results.

The table below presents the geographical frequency distribution of respondents while the figure illustrates the percentage allotment of journalists who filled and returned complete questionnaires.

\begin{tabular}{|c|c|}
\hline Clusters & Frequency \\
\hline Sindh & 116 \\
\hline Baluchistan & 43 \\
\hline Islamabad Rawalpindi & 66 \\
\hline KPK & 51 \\
\hline Punjab & 44 \\
\hline Total & 320 \\
\hline
\end{tabular}

Table no. 1

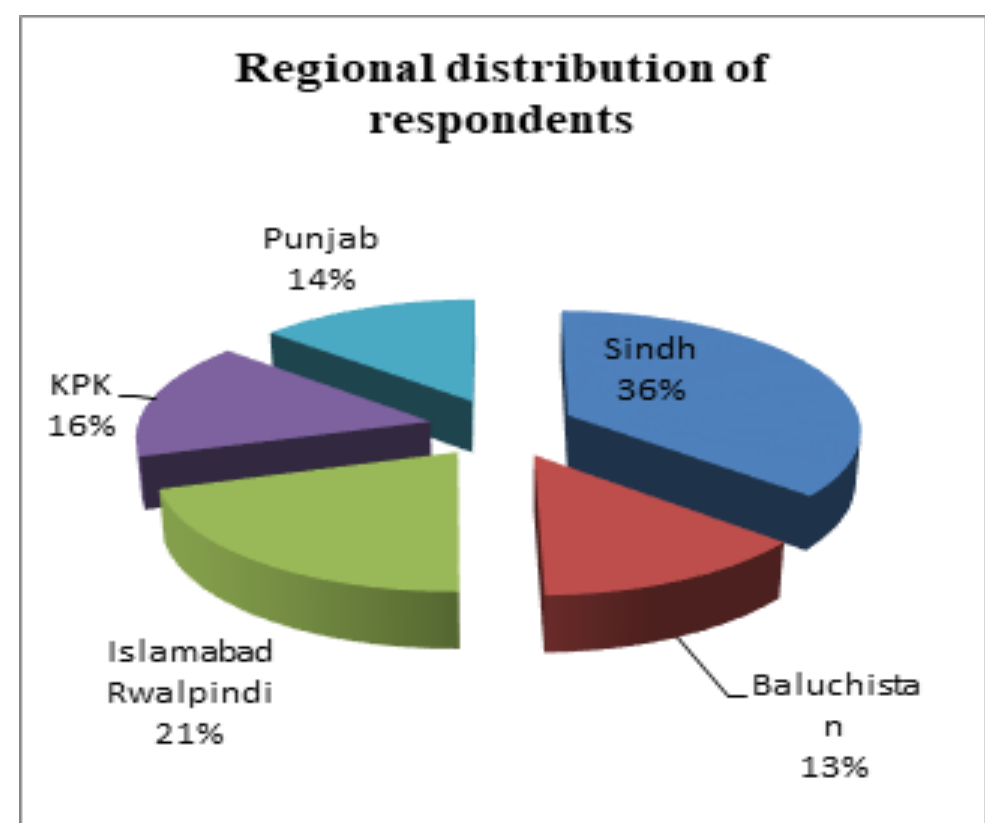

Interpretation: The statistics shows that most $(36 \%)$ of the responses came from Sindh followed by Islamabad Rawalpindi, KPK, Punjab and Baluchistan at 21\%, $16 \%, 14 \%$ and $13 \%$ respectively. 
Journalists in Sindh are more responsive, mostly due to Karachi as the most populous city and the economical hub of the state. The figure depicts the responding mode and dynamics of media persons in different geographical regions of the country.

The demographic distribution of respondents represents the population of working journalists in Pakistan which is assumed twenty thousand ratified by Pakistan Press Foundation (PPF) and International Media Support (IMS) and that validates and makes reliable the study for acceptable generalization with 1.6 percent sample size.

\section{Existence of threats}

Threats are congenital to journalism and to journalists but less or more divergent in approaches and dimensions in different societies, regions and states of the world. According to Committee to Protect Journalists (CPJ, 2019), 1338 journalists are killed in the line of their duties during the last 17 years.

The existence of threats to journalists in Pakistan is located here below after the confessions of sampled journalists.

The following table shows frequency distribution of the confessions of sampled journalists from the media landscape of the country while the figure illustrates the responses when journalists were asked whether they had faced with threats for their professional jobs.

\begin{tabular}{|c|c|c|}
\hline \multirow{2}{*}{$\begin{array}{c}\text { Have you faced any } \\
\text { threat in the line of duty? }\end{array}$} & \multicolumn{2}{|c|}{ Frequency } \\
\cline { 2 - 3 } & Yes & NO \\
\cline { 2 - 3 } & 135 & 185 \\
\hline Total & 320 & \\
\hline
\end{tabular}

Table no. 2

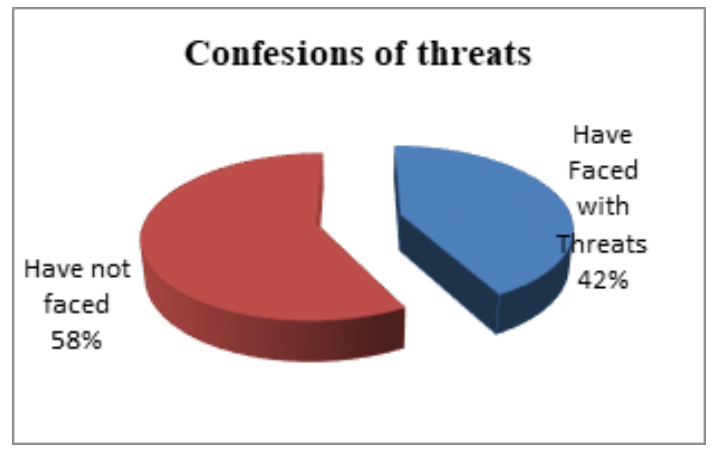

Interpretation: The data reveals that slightly less (42\%) than half of journalists confessed threats while slightly more $(58 \%)$ responded no threats in the line of their journalistic works. 
Findings affirm the threats, although, the intensity is less than fifty percent but $42 \%$ is even then alarming which urges a hankering appeal to be redressed and be further studied as a significant factor for measurements in the area of strengthening press freedom in the country.

\section{Dimensions of threats}

The very profession of journalisms instigates threats because journalists are the "Watch Dogs" and safeguard the right of expression of individuals and make the government and its institutions accountable in accordance to law and in pursuance to the moralities of the society. But the new trends, modified tactics and multidimensional sources of threats are more important to be explored in the new dilemmas of the concurrent situation of media environment in Pakistan's context. The study, below, empirically locates the most imp active dimensions of threats to journalists.

\section{Constitutional dimension}

The constitution of Islamic Republic of Pakistan (1973) in its article 19 and 19A, guarantees the freedom of expression but confines it at the same time (CoP, 1973). The article 19 says that "Every citizen shall have the right to freedom of speech and expression and there shall be freedom of press". But the constitution also subjects these freedoms to the glory of Islam, integrity and security of the state, to the friendly relations with foreign states, to the public order, decency and morality, to the court and to any incitement to an offence. Similarly, article 19A guarantees accesses to information but that is also subjected to restrictions imposed by law. But the frame of freedom of press, prescribed by the Universal Declaration of Human Rights (1948) which says that everyone has right to hold opinion and expression without any interference and regardless of frontier.

Restrictions and their validation create a very complex situation because the interests differ from person to person and from institution to institution (Mirza, 2018). It is not so simple to confine world in mono-dimensional interpretation and so is the criterion of the impacts of speeches. In hostile circumstances law and their ambiguity is always misused which threaten the practitioners and lead to the obstruction of freedom.

In a study on the freedom of expression in China, Yiyao Zhang (2010), declares that although the country's constitution guarantees the freedom of expression but in practice, this freedom is under the strict control of the government at all levels. In the same way, in this sense the guarantees granted by the constitution embodied in restrictions are in no way the assurance of freedom of press.

\section{Legal dimension}

Statutory law in Pakistan is a legacy of colonial era which the Law Commission drafted and was passed by the Legislative Council in October 1860. Pakistan adopted name of Pakistan Penal Codes (PPC) under the Independence Act 1947. The Penal Codes made in 1860, are still in practice. Little amendments have been made to it but in sections pertaining to the freedom of expression and press, no improvement have been made rather making it further restrictive from time to time. 
The PPC's section 123-A, section 124-A, section 153-A, section 153-B, section 192, section 195-A, section 499 and section 500 (PPC, 1860) impose restrictions on the freedom of press and the tricky use of these frothing shields are consistently threatening journalists to report in the respected areas.

In addition to the colonial laws such as Censorship Law Modifications (1813), Regulations for Registration (1823), Metcalf's Act (Registration of Press Act) 1835, New Regulations on Printing Presses (1857), Press and Registration Act 1867, Vernacular Press Act (1878), Newspapers Act (1908), Indian Press Act (1910), Official Secret Act (1923) and Indian Press, Emergency Power Act 1931, special press laws like Security of Pakistan Act (1952), Press and Publication Ordinance 1960, the Press and Publication (amendment) Ordinance (1963), Defense of Pakistan Ordinance (1965), Promulgation of Martial Law Rules 6, 17, 19 (1969), Promulgation of Martial Law Rule 110 (1971), Registration of Printing press and Publication Ordinance (1988), Freedom of Information Ordinance (1997), Press, Newspapers, News Agencies and Books Registration Ordinance (2002), Press Council of Pakistan Ordinance (2002), Defamation Law (2002), PEMRA Ordinance (2002), Freedom of Information Ordinance (2002), PEMRA Act [Amendment] (2007), PEMRA Rules (2009) and Code of Conduct (2010), Right to Information (2010), PEMRA (Distribution Service Operation) Regulation (2011) and PEMRA (Radio Broadcast Station Operation) Regulations (2012) are contiguously confining the freedom of press in Pakistan.

This frame of legal restriction handicaps the progress in journalistic professionalism and amplifies threats to journalists.

\section{Political dimension}

Politics-media nexus in the contexture of political communication and economical ties is impetus to threats to journalists. Although, press, in its first phase, after it was invented by Gutenberg in 1450, was used for religious purposes but as soon as political powers surpasses the religion, political ambitions of the time ruthlessly used it for political motives and at large subjugated it.

The roots of political interference in media content in Pakistan are history old and has a colonial legacy sustained by native political lords (Anwar and Jan, 2010). Strengthening the perception, Huma Yusuf and Schomaker (2010), declare that politicization in Pakistan sternly pressurizes journalists and press for vested interests. Similarly, Dr. Sajjad Ahmed Paracha (2008) proclaims that political parties bribe journalists and media owners for vested interests and also journalists have political affiliations that grow threats for journalists and for the profession.

More in this respect, A.H. Khanzada (2018), denotes that most of the journalists are constantly in correlation with political ideologies on the expenses of professionalism and that bears threats for them.

It is important to investigate political aspect of threats to journalists in the media environment of the country, consulting working journalists for being a cordial part of the play. The statistics below locate the variable in an empirical manner to facilitate understanding regarding this area of study. 
The following table summarizes perceptions of working journalists about political affiliation of journalists while the figure demonstrates percentage distribution of responses when respondents were asked whether journalists have political affiliations in Pakistan.

\begin{tabular}{|c|c|c|}
\hline \multirow{2}{*}{$\begin{array}{c}\text { Have journalists' political } \\
\text { affiliation in Pakistan? }\end{array}$} & \multicolumn{2}{|c|}{ Frequency } \\
\cline { 2 - 3 } & Yes & NO \\
\cline { 2 - 3 } & 294 & 12 \\
\hline Have no idea & \multicolumn{2}{|c|}{14} \\
\hline Total & \multicolumn{2}{|c|}{320} \\
\hline
\end{tabular}

Table no. 3

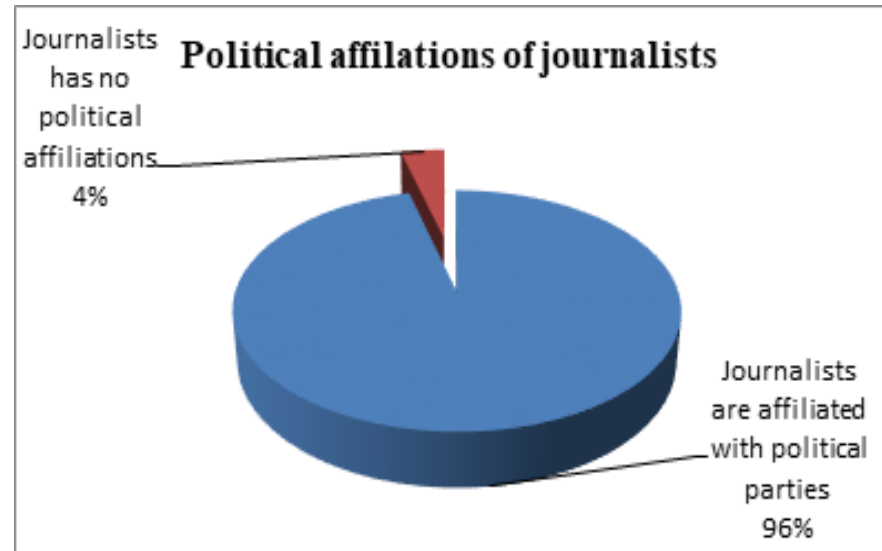

Interpretation: A very vast majority (96\%) of the respondents opined that journalists in Pakistan have political affiliations, denoting the most dangerous quandary of professionalism. The four percent non-affiliated journalists are not enough to go ahead.

Findings reveal that the Pakistan's media environment is almost biased and doesn't deserve to be free before inculcating professionalism in it. Measures in an earnest and consistent manner are necessary to stop political persuasions and to mend all possible linkage in this connection.

\section{Economical dimension}

The route to honesty and professionalism passes through stomach (Tahir, 2018) so that economy is cordial to journalistic professionalism. Most of the journalists belong to middle class with tensed economical position and also journalists receive very nominal salaries with no job security (Khan, 2018) that makes them vulnerable to be bribed and to be misused for favouritism that enshrines threats to journalists (Abbasi, 2018). 
Most of the journalists in Quetta work as part-timers due to low salaries and more side benefits (Chaudhri, 2018) and that are the situations in all regions of the state. In a study by Abida Eijaz (2014), this factor was confirmed and also by Sherry Ricchiardi (2012). Similarly senior journalist Mazhar Abbas (2018) in his article acknowledges the economical move on the back of news contents.

This study establishes the economical ambitions behind the media business in Pakistan, scrutinizing perceptions of working journalists.

The table below summarizes responses of sampled journalists regarding ambitions of journalists for joining media as a profession while the figure illustrates results when respondents were asked whether journalists join media for economical interests.

\begin{tabular}{|c|c|c|}
\hline \multirow{2}{*}{$\begin{array}{c}\text { Do journalists join media } \\
\text { for economical interests? }\end{array}$} & \multicolumn{2}{|c|}{ Frequency } \\
\cline { 2 - 3 } & Yes & NO \\
\cline { 2 - 3 } & 276 & 18 \\
\hline Have no idea & \multicolumn{2}{|c|}{26} \\
\hline Total & \multicolumn{2}{|c|}{320} \\
\hline
\end{tabular}

Interpretation: Table and figure indicate that media industry in Pakistan is fully commercial and completely lack professionalism. An overwhelming majority (94\%) affirm the economical ambition of journalists for joining media as a profession while only $6 \%$ opined no such interests behind the job of journalism.

Findings indicate that journalists in Pakistan are no more professional and only work as a job with multiple chances for collateral gains. It is potential to dig it out, why journalists don't cohere with professional characteristic, norms, values and international standards. Answer to this dilemma is being searched in hindrances in the way to professionalism.

\section{Social dimension}

Media works for society to get momentum in the development archetype of democratization and nation building. By principle media and society are intertwined and symbiotic but in practice become diverse, especially in eastern and third world, if that is heterogenic and have low tolerance for criticism. Societies which are badly stricken to fundamentalism and are weaved in multiple ties of ideologies, cultures and ethnicity; intricate the media-society relation creating threats and results in violence against journalists.

Pakistan's media history reflects a number of such violent reactions like attacks on Press Clubs, media houses and journalists. Recently, unknown culprits tormented journalist Asad Kharal in Lahore; he was working as anchorperson for BOl TV. Kharal got injuries and was hospitalized (Dawn June 06, 2018). Journalist Zeeshan 
was shot dead by a local politician in Sialkot (Dawn Mar. 28, 2018)

The above and more other instances demonstrate a high level of intolerance for press's criticism in Pakistani society. A more scientific evaluation is attempted by this study as below to locate the intensity of intolerance in society for press's criticism.

The following table summarizes responses of sampled journalists regarding the presence of intolerance in society regarding press's criticism while the figure illustrates the results when working journalists were asked whether level of intolerance for press's criticism is high, normal or low.

\begin{tabular}{|l|l|}
\hline $\begin{array}{l}\text { Level of intolerance in society for press's } \\
\text { criticism }\end{array}$ & Frequency \\
\hline $\begin{array}{l}\text { Level of intolerance in society for press's } \\
\text { criticism is high }\end{array}$ & 160 \\
\hline Level of intolerance in society is normal & 139 \\
\hline $\begin{array}{l}\text { There is no intolerance in the society for } \\
\text { press's criticism }\end{array}$ & 21 \\
\hline Total & 320 \\
\hline
\end{tabular}

Table no. 4

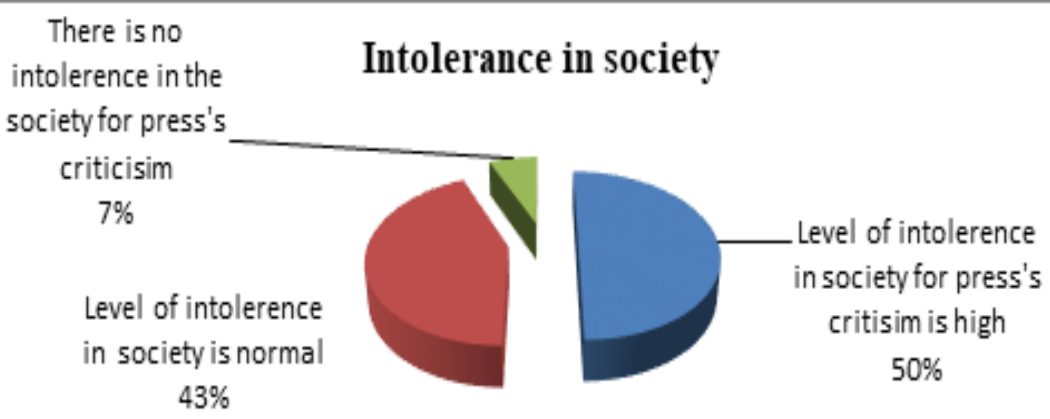

Interpretation: The table and figure reveal that intolerance in Pakistani society for press's criticism is high as $50 \%$ of respondents confirm it. Forty three percent of the respondents affirm normal tolerance while only $7 \%$ reply in no intolerance for press's criticism.

Findings highlight the existence of intolerance for press's criticism which lead to threat to journalists and press. This state of affairs urges to strengthen media-society ties through dialogue mechanism among the stake holders and confidence building measures should be drafted for smoothing the environment for creative and positive criticism of the press. 


\section{Rule of law}

Media as a tool and journalists as factors of investigation and accountability provoke threats inevitably, from the individuals, groups and institutions that are involved in illegal practices which lead to pressure and demands complete rule of law because when rule of law is weak severer will be the reaction and journalists and the profession will be badly suffered (Zaidi, 2018).

Unfortunately, in Pakistan, the rule of law is feeble and the law and order situation is not good, as a result journalists are exposed to threats and they are compelled to exercise self-censorship on the expenses of professionalism or they become part of the nasty game (Zulfiqar, 2018).

The deteriorated situation of rule of law in Pakistan is reflected in the indices of World Justice Project (WJP) where Pakistan secures position in the lower ten while this study explores Pakistan's media environment in journalists' perspectives to locate the level of rule of law.

The table below summarizes distribution of perceptions of working journalists while the figure illustrates results when the sampled journalists were asked whether situation of rule of law is strong, normal or weak in Pakistan.

\begin{tabular}{|l|l|}
\hline Levels of rule of law in Pakistan & Frequency \\
\hline Situation of rule of law is strong & 13 \\
\hline Situation of rule of law is normal & 137 \\
\hline Situation of rule of law is weak & 170 \\
\hline Have no idea & 0 \\
\hline Total & 320 \\
\hline
\end{tabular}

Table no. 5

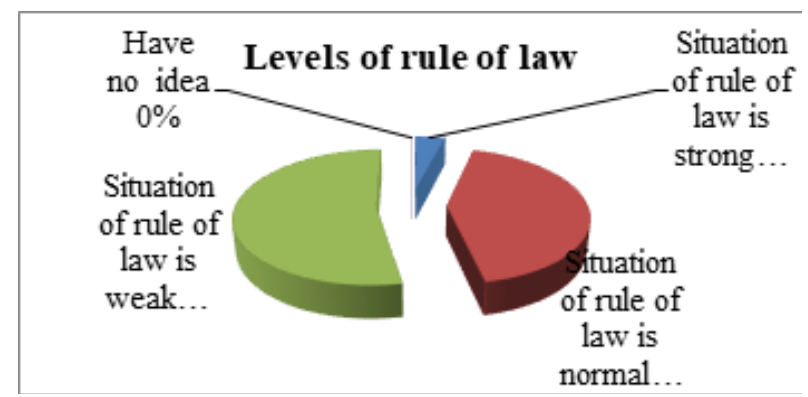

Interpretation: The table and figure situation of rule of law is dangerously weak as more than half $(53 \%)$ of the working journalists perceived that. Forty three percent of the respondents opined that rule of law is normal but only four percent confirmed strong hold of the rule of law. 
Findings demonstrate a devastating and alarming situation regarding the rule of law. The rule of law is the first condition for democratization, development and security. The weak position of rule of law certainly endangers journalists to maintain professional job which assure transparency and accountability.

\section{Sources of threats}

After the presence of threats to journalists was established and 135 of 320 journalists confessed that they had received threats in the line of their duty, it is important to locate the sources of threats for effective measures to be taken in this area of significance.

In research article, Sadia Jamil (2018) concludes that threats to journalists come from government, military, militants, political parties, religious groups or media owners. This research affirms the some of the sources in a normative manner. Adding to this conception, Huma Yusuf and Emrys Schomaker (2013) declare that media in Pakistan freer but still vulnerable to state control.

A generally held view is that state and non-state agents put pressure and are threatening journalist for vested interests but no study had ever nominated the factual sources. This study allocates the real sources behind threats, confessed by working journalist in the media environment of Pakistan.

The following table summarizes responses of working journalists regarding the sources of threats while the figure illustrates the results when sampled journalists were asked who was behind the threats that journalists had faced with during their professional jobs.

\begin{tabular}{|c|c|}
\hline Sources behind threats & Frequency \\
\hline The governing Party & 14 \\
\hline The Opposition parties & 11 \\
\hline Establishment & 18 \\
\hline Law enforcement agencies & 11 \\
\hline Traffickers & 12 \\
\hline Land grabbers & 10 \\
\hline Militants & 14 \\
\hline Religious Groups & 13 \\
\hline Social Activists & 3 \\
\hline Economical Interest Groups & 10 \\
\hline
\end{tabular}




\begin{tabular}{|c|c|}
\hline Individuals & 18 \\
\hline Unknown & 36 \\
\hline Total & 170 \\
\hline
\end{tabular}

Table no. 6

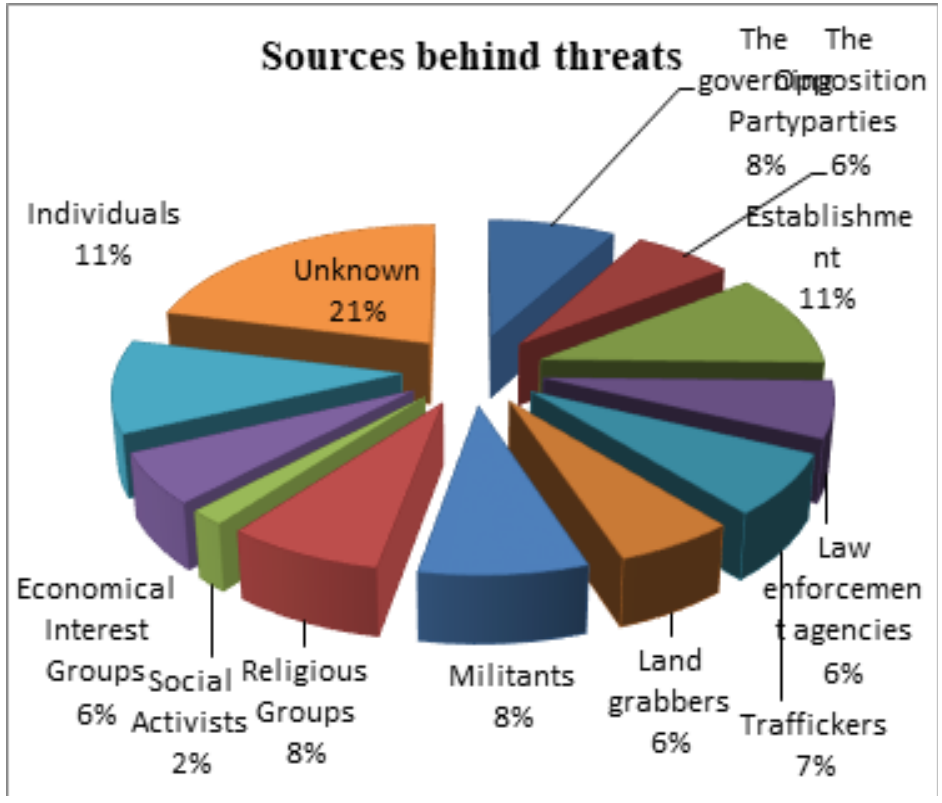

Interpretation: Statistics show that the prodigious (21\%) source of threats confessed by journalists is "unknown" following by "individuals" and "establishment" at $11 \%$ each. The governing parties, militants and religious groups are on third stage at $8 \%$ each. Traffickers are at $7 \%$ securing fourth place. The opposition parties, law enforcement agencies, land grabbers and economical interest groups are making $6 \%$ share in threats on fifth position while social activists are the least at $2 \%$ holding journalists in threats to journalists.

Findings indicate a desecrating situation and portray a dreading environment where journalists are fully exposed to threats. The confessions reveal that the whole society and all its institutions are threatening and pressurising journalists for vested interests. The state of affairs is hankering to be properly and empirically addressed the prevailed dilemma.

The biggest source as "Unknown" is ultra important to be redressed because that is the most dangerous conundrum and a fear of all times and from all dimensions.

\section{Impacts of threats}

The severity of threats is also necessary to be located and as a confession, the reliability is more authentic which this study attempts to achieve asking journalists who had received threats in the line of their duty. 
The following table summarizes the frequency of impacts of threats on the working capacities of journalists while the figure illustrates percentage distributions of the results when threatened journalists were asked whether threats had affected their working capacities.

\begin{tabular}{|c|c|c|}
\hline \multirow{2}{*}{$\begin{array}{c}\text { Did threats in the line of } \\
\text { duty affect your working } \\
\text { capacities? }\end{array}$} & Yes & NO \\
\cline { 2 - 3 } & 57 & 78 \\
\hline Total & 135 & \\
\hline
\end{tabular}

Table no.7

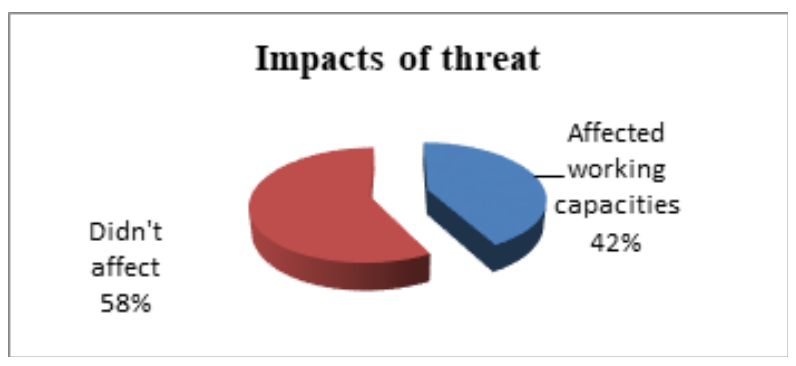

Interpretation: The table and figure reveal that slightly more than half $(58 \%)$ of the journalists affirmed that threats had not affected their journalistic capacities but slightly less than half (42\%) confessed that threats had affected their working capacities.

The predicament suggests that journalists are brave enough to face threats keeping their profession uphold but the confession in term of affects is alarming and need adequate arrangements to be ameliorated.

\section{CONCLUSION}

The study properly addressed the threats dilemma prevailed in Pakistan for journalists and located the sources and the causes after establishing threats. Following the findings, it is fair to conclude that reverently, journalists are faced with multiple threats to carry on their professional duties. Although less than half but $42 \%$ of working journalists confessed that they have confronted threats in the line of their duty, which is alarming in its intensity and implications.

The basic question of the study that who threats journalists in Pakistan gets reply very explicitly in terms of confessions. During the survey 230 journalists responded the close ended questions and threats were confessed by $135(42 \%)$. The supplementary question that who have threatened them was replied by all the journalists who had faced with threats for journalistic works and 170 responses were recorded because some of the threatened journalists nominated multiple 
sources. The results are enough clear to conclude that unknown culprits are the most frequently and the biggest source of threats to journalists and the most treacherous in its nature. The governing and opposition parties, the religious groups, social activists and individuals as sources of threats to journalists are the product of intolerance for press's criticism in the society. The law enforcement agencies, the traffickers, economical interests groups and grabbers are the sources of threats based on their corruption and illegality. But these confessions authenticate that press in Pakistan is not free in any sense and journalists are working in a perilous environment. All the influential factors are threatening journalists and put pressure on media content which reflect a state of low rule of law and weak law and order situation in the country.

The second question is satisfied by the results of perceptions of senior journalists and by survey's findings decidedly. The low level of rule of law, low tolerance in society for press's criticism, high and irrational ambitions of power lusty politicians, high level of corruption, lapse in duty performances of law-enforcement agencies, politically supported motives of individuals and undeclared vested interests of unknowns and lucrative economical gains in trafficking and land grabbing are causes of threats on one hand while low salary packages, no job security, economical interests of media owners, vested interests of journalists, blackmailing and misuse of media powers of media persons, no security mechanism for journalist and no proper forum for threats' redresses are on the other hand.

\section{Implications for Research}

This study attempted to discover the existence of threats and most of their sources spread over the media landscape of Pakistan but still full-length academic research is needed to evaluate all the possible dimensions of the media environment in relation to security risks and threats to journalists. It is also important to check professionalism and all its aspects in the media landscape of the country to provide more understandable guidelines for policy making in this area of impacts.

\section{REFERENCES}

Zhang, Yiyao (2010). The right to freedom of expression versus media censorship in China: Chinese citizens and the Internet. MS thesis. Universitetet i Tromsø.

CoP. (1973). Constitution of Islamic Republic of Pakistan. Retrieved from http:// www.pakistani.org/pakistan/constitution/

CPJ. (2019). 1338 Journalists killed (1992-2019). Retrieved from https://cpj. org $/$ data/killed $/$ ?status $=$ Killed\&motiveConfirmed $\% 5 \mathrm{~B} \% 5 \mathrm{D}=$ Confirmed\&type $\% 5 B \% 5 \mathrm{D}=$ Journalist\&start_year=1992\&end_year=2019\&group_by=year

UDHR. (1948). Universal Declaration of Human Rights. Retrieved from https:// www.un.org/en/universal-declaration-human-rights/

Mirza, Mudasir (Sep. 13, 2018). Personal Interview at the office of daily Jang Karachi.

PPC. (1860). Pakistan Penal Codes. Retrieved from http://www.pakistani.org/pakistan/legislation/1860/actXLVof1860.html

Anwar, M., \& Jan, M. (2010). Role of Media in Political Socialization: The Case of 
Pakistan. Dialogue (Pakistan), 5(3).

Yusuf, Huma and Shoemaker, Emrys (2013). The Media of Pakistan. Retrieved July,23,2017 from http://downloads.bbc.co.uk/mediaaction/pdf/bbc_media action_pakistan_policy_briefing.pdf

Paracha, Ahmed, Sajjad (2008). Pakistan Media Policy: A normative approach. $\mathrm{PhD}$. Thesis submitted to the University of Punjab

Khanzada, A.H. (Oct. 16, 2018). Personal Interview at the office of Neo TV Karachi Tahir, Nawaz (Apr. 15, 2018). Personal Interview at Lahore Press Club: Lahore

Abbasi, Khursheed (Oct. 22, 2018). Personal Interview at the office of daily Awam: Karachi

Khan, Ibrahim (May 16, 2018). Personal Interview at residence of the journalist: Peshawar

Chaudhri, Imtiaz (sep. 20, 2018). Personal Interview at the office of daily Mashriq: Quetta

Eijaz, A., Rahman, B. H., Ahmad, R. E., \& Butt, J. A. (2014). Challenges and options for Pakistani media in the 21st century. Journal of Political Studies.

Ricchiardi, S. (2012). Challenges for independent news media in Pakistan. Washington, DC: Center for International Media Assistance.

Abbas, Mazhar (Jan. 31, 2018). New Challenges to Media. Daily Dawn: Karachi. Retrieved from https://www.thenews.com.pk/print/275077-new-challenges-tomedia

Dawn (Jun. 06, 2018). Journalist Asad Kharal beaten up by masked men in Lahore. Retrieved from https://www.dawn.com/news/1412385

Dawn (Mar. 28, 2018). UC chairman shoots journalist in Sialkot. Retrieved from https://www.dawn.com/news/1397944

Zaidi, Nasir (Apr. 25, 2018). Personal Interview at National Press Club: Islamabad Zulfiqar, Shahzada (Sep. 23, 2018). Personal Interview at the office of Bol TV: Quetta

Jamil, Sadia (2018). Safety Threats, Impunity and Professionalism: Journalists' Dilemma in Pakistan. Sociology and Anthropology 6(7): 571-578, 2018. Retrieved from http://www.hrpub.org

Yusuf, H., \& Schoemaker, E. (2013). The media of Pakistan. BBC Media Action. Retrieved from http://downloads.bbc.co.uk/mediaaction/pdf/bbc_media_action pakistan policy briefing.pdf

WJP. (2019). World Justice Project. Retrieved from https://worldjusticeproject.org/

IPFM. (May, 2018). International Press Freedom Mission to the United States. Retrieved from https://www.article19.org/wp-content/uploads/2018/05/PressFreedom-Under-Threat-International-Press-Freedom-Mission-to-the-UnitedStates.pdf

Siddiqui, Ameen, Furquan (2017). Threats to Journalists in India: Journalism in the Age of intolerance and Rising Nationalism. Retrieved from https://reutersinstitute.politics.ox.ac.uk/sites/default/files/2018-08/Threats\%20to\%20Journalists $\% 20 \mathrm{in} \% 20$ India $\% 20 \mathrm{Journalism} \% 20 \mathrm{in} \% 20$ the $\% 20 \mathrm{Age} \% 20 \mathrm{of} \% 20$ Intolerance $\% 20$ and $\% 20$ Rising\%20Nationalism.pdf

Elliott, S., Elbahtimy, M., \& Srinivasan, S. (2012). Threats to the Right to Life of Journalists. Retrieved from https://www.repository.cam.ac.uk/bitstream/handle/1810/245114/CGHR_WP 4 2012_Journalists-Report.pdf?sequence $=4$

Cook, Sarah (2013). The Long Shadow of Chinese Censorship: A Report to the Cen- 
ter for International Media Assistance, Retrieved May 15, 2017 from ttp://freedomhouse.org/sites/default/files/CIMA-China_Sarah\%20Cook_10_22_13.pdf Bajomi-Lázár, Péter (2003). Freedom of the Media in Hungary, 19990-200․ Diss. PhD dissertation, Political Science Department, Central European University, Budapest.

Skamnakis, Antonis (2006). Politics, media and journalism in Greece. Diss. Dublin City University.

Wiratraman, H. P. (2014). Press freedom, law and politics in Indonesia: a socio-legal study. Institute for the Interdisciplinary Study of the Law, Van Vollenhoven Institute, Faculty of Law, Leiden University.

Khan, Wasatullah (May 15, 2018). Personal Interview at Karachi Press Club: Karachi

killed/?status =Killed\&motiveConfirmed $\% 5 \mathrm{~B} \% 5 \mathrm{D}=$ Confirmed\&type $\% 5 \mathrm{~B} \% 5 \mathrm{D}=-$ Journalist\&start year $=1992 \&$ end year $=2019 \&$ group by $=$ year

UDHR. (1948). Universal Declaration of Human Rights. Retrieved from https:// www.un.org/en/universal-declaration-human-rights/

Mirza, Mudasir (Sep. 13, 2018). Personal Interview at the office of daily Jang Karachi.

PPC. (1860). Pakistan Penal Codes. Retrieved from http://www.pakistani.org/pakistan/legislation/1860/actXLVof1860.html

Anwar, M., \& Jan, M. (2010). Role of Media in Political Socialization: The Case of Pakistan. Dialogue (Pakistan), 5(3).

Yusuf, Huma and Shoemaker, Emrys (2013). The Media of Pakistan. Retrieved July,23,2017 from http://downloads.bbc.co.uk/mediaaction/pdf/bbc_media action pakistan policy briefing.pdf

Paracha, Ahmed, Sajjad (2008). Pakistan Media Policy: A normative approach. $\mathrm{PhD}$. Thesis submitted to the University of Punjab

Khanzada, A.H. (Oct. 16, 2018). Personal Interview at the office of Neo TV Karachi Tahir, Nawaz (Apr. 15, 2018). Personal Interview at Lahore Press Club: Lahore

Abbasi, Khursheed (Oct. 22, 2018). Personal Interview at the office of daily Awam: Karachi

Khan, Ibrahim (May 16, 2018). Personal Interview at residence of the journalist: Peshawar

Chaudhri, Imtiaz (sep. 20, 2018). Personal Interview at the office of daily Mashriq: Quetta

Eijaz, A., Rahman, B. H., Ahmad, R. E., \& Butt, J. A. (2014). Challenges and options for Pakistani media in the 21st century. Journal of Political Studies.

Ricchiardi, S. (2012). Challenges for independent news media in Pakistan. Washington, DC: Center for International Media Assistance.

Abbas, Mazhar (Jan. 31, 2018). New Challenges to Media. Daily Dawn: Karachi. Retrieved from https://www.thenews.com.pk/print/275077-new-challenges-tomedia

Dawn (Jun. 06, 2018). Journalist Asad Kharal beaten up by masked men in Lahore. Retrieved from https://www.dawn.com/news/1412385

Dawn (Mar. 28, 2018). UC chairman shoots journalist in Sialkot. Retrieved from https://www.dawn.com/news/1397944

Zaidi, Nasir (Apr. 25, 2018). Personal Interview at National Press Club: Islamabad Zulfiqar, Shahzada (Sep. 23, 2018). Personal Interview at the office of Bol TV: 


\section{Quetta}

Jamil, Sadia (2018). Safety Threats, Impunity and Professionalism: Journalists' Dilemma in Pakistan. Sociology and Anthropology 6(7): 571-578, 2018. Retrieved from http://www.hrpub.org

Yusuf, H., \& Schoemaker, E. (2013). The media of Pakistan. BBC Media Action. Retrieved from http://downloads.bbc.co.uk/mediaaction/pdf/bbc_media_action pakistan policy_briefing.pdf

WJP. (2019). World Justice Project. Retrieved from https://worldjusticeproject.org/

IPFM. (May, 2018). International Press Freedom Mission to the United States. Retrieved from https://www.article19.org/wp-content/uploads/2018/05/PressFreedom-Under-Threat-International-Press-Freedom-Mission-to-the-UnitedStates.pdf

Siddiqui, Ameen, Furquan (2017). Threats to Journalists in India: Journalism in the Age of intolerance and Rising Nationalism. Retrieved from https://reutersinstitute.politics.ox.ac.uk/sites/default/files/2018-08/Threats\%20to\%20Journalists $\% 20 \mathrm{in} \% 20$ India $\% 20 \mathrm{~J}$ ournalism $\% 20 \mathrm{in} \% 20$ the $\% 20 \mathrm{Age} \% 20 \mathrm{of} \% 20$ Intolerance $\% 20$ and $\% 20$ Rising\%20Nationalism.pdf

Elliott, S., Elbahtimy, M., \& Srinivasan, S. (2012). Threats to the Right to Life of Journalists. Retrieved from https://www.repository.cam.ac.uk/bitstream/handle/1810/245114/CGHR_WP_4_2012_Journalists-Report.pdf? sequence=4

Cook, Sarah (2013). The Long Shadow of Chinese Censorship: A Report to the Center for International Media Assistance ,Retrieved May 15, 2017 from ttp://freedomhouse.org/sites/default/files/CIMA-China_Sarah\%20Cook_10_22_13.pdf Bajomi-Lázár, Péter (2003). Freedom of the Media in Hungary, 19990-200․ Diss. PhD dissertation, Political Science Department, Central European University, Budapest.

Skamnakis, Antonis (2006). Politics, media and journalism in Greece. Diss. Dublin City University.

Wiratraman, H. P. (2014). Press freedom, law and politics in Indonesia: a socio-legal study. Institute for the Interdisciplinary Study of the Law, Van Vollenhoven Institute, Faculty of Law, Leiden University.

Khan, Wasatullah (May 15, 2018). Personal Interview at Karachi Press Club: Karachi 